\title{
Inflammatory mediators of proliferative vitreoretinopathy: hypothesis and review
}

\author{
Ying Dai · Chenghua Dai · Tao Sun $\mathbb{C}$
}

Received: 26 June 2019/ Accepted: 15 February 2020/Published online: 26 February 2020

(C) The Author(s) 2020

\begin{abstract}
Purpose To review the role of inflammatory mediators in proliferative vitreoretinopathy (PVR) development and the current treatment for PVR prevention. Methods A PubMed search was carried out using these keywords "PVR," "inflammatory mediators," "growth factors," "cytokines" and "treatment." Studies regarding inflammatory mediators and PVR therapy were included and published up to December 2019.

Results Inflammatory mediators, namely growth factors and cytokines, have been implicated in the occurrence and development of PVR. Among various inflammatory mediators, transforming growth factor$\beta$, platelet-derived growth factor, interleukin-6, interleukin- 8 and tumor necrosis factor- $\alpha$ are considered to be particularly important. In this review, we focus on the hypothesis that growth factors and cytokines are involved in the development of PVR, and current treatment for the prevention of PVR.
\end{abstract}

\section{Y. Dai · T. Sun $(\bowtie)$}

Department of Ophthalmology, The First People's Hospital of Yancheng, No. 10, Nancheng River Road, Yancheng 224000, Jiangsu Province, China

e-mail: Suntao_13003@163.com

C. Dai

Department of Ophthalmology, Yangzhou Hospital of Traditional Chinese Medicine Affiliated to Nanjing University of Chinese Medicine, Yangzhou 225000, Jiangsu Province, China
Conclusion We support the hypothesis that growth factors and cytokines may participate in the complex process of PVR development. More importantly, the identification of inflammatory mediators provides novel and efficacious therapeutic targets for the treatment of PVR.

Keywords Proliferative vitreoretinopathy (PVR) . Inflammatory mediators · Growth factors · Cytokines . Treatment

$\begin{array}{ll}\text { Abbreviations } \\ \text { AH } & \text { Aqueous humor } \\ \text { ANGPT } & \text { Angiopoietin } \\ \text { BCVA } & \text { Best-corrected visual acuity } \\ \text { COX } & \text { Cyclooxygenase } \\ \text { ECM } & \text { Extracellular matrices } \\ \text { EMT } & \text { Epithelial-mesenchymal transition } \\ \text { EGF } & \text { Epidermal growth factor } \\ \text { bFGF } & \text { Basic fibroblast growth factor } \\ \text { 5-FU } & \text { 5-Fluorouracil } \\ \text { HGF } & \text { Hepatocyte growth factor } \\ \text { ICAM-1 } & \text { Intercellular adhesion molecule-1 } \\ \text { IL } & \text { Interleukin } \\ \text { LMWH } & \text { Low molecular weight heparin } \\ \text { MDM2 } & \text { Mouse double minute 2 } \\ \text { MMP } & \text { Matrix metalloproteinase } \\ \text { NSAIDs } & \text { Nonsteroidal anti-inflammatory drugs } \\ \text { PDGF } & \text { Platelet-derived growth factor } \\ \text { PDGFR } & \text { PDGF receptor }\end{array}$




$\begin{array}{ll}\text { PGD }_{2} & \text { Prostaglandin } \mathrm{D}_{2} \\ \text { PGD }_{2} \mathrm{~S} & \text { Prostaglandin } \mathrm{D}_{2} \text { synthase } \\ \text { PGE }_{2} & \text { Prostaglandin } \mathrm{E}_{2} \\ \text { mPGES } & \text { Membrane-associated prostaglandin } \\ & \text { E-synthase } \\ \text { PPV } & \text { Pars plana vitrectomy } \\ \text { PVR } & \text { Proliferative vitreoretinopathy } \\ \text { RCTs } & \text { Randomized clinical trials } \\ \text { RD } & \text { Retinal detachment } \\ \text { lncRNA } & \text { Long noncoding RNA } \\ \text { RNAi } & \text { RNA interference } \\ \text { ROCK } & \text { Rho-kinase } \\ \text { ROS } & \text { Reactive oxygen species } \\ \text { RPE } & \text { Retinal pigment epithelial } \\ \text { RRD } & \text { Rhegmatogenous retinal detachment } \\ \text { rAAV } & \text { Recombinant adeno-associated virus } \\ \text { SKFs } & \text { Src family kinases } \\ \text { SNP } & \text { Single-nucleotide polymorphism } \\ \text { sTNF-R } & \text { Soluble TNF-receptor } \\ \text { TA } & \text { Triamcinolone acetonide } \\ \text { TAK1 } & \text { Transforming growth factor beta-activated } \\ & \text { kinase 1 } \\ \text { TGF- } \beta & \text { Transforming growth factor- } \beta \\ \text { TNF- } \alpha & \text { Tumor necrosis factor- } \alpha \\ \text { TRD } & \text { Tractional retinal detachment } \\ \text { UTMD } & \text { Ultrasound-targeted microbubble } \\ \text { VEGF } & \text { destruction } \\ & \text { Vascular endothelial growth factor }\end{array}$

\section{Introduction}

Proliferative vitreoretinopathy (PVR) was coined by the Retina Society Terminology Committee in 1983 to describe a disease process occurring secondary to rhegmatogenous retinal detachment (RRD) [1-3]. PVR is estimated to cause approximately $5-10 \%$ of all retinal detachments $[4,5]$. Patients with a long history of untreated RRD, large retinal breaks or retinal tears, multiple retinal breaks, extensive detachments or choroidal detachment are at a higher risk of progressing into PVR [4, 6]. In addition, PVR can occur in patients with ocular trauma, intraocular inflammation or after retinal procedures including retinal cryopexy, laser retinopexy, pneumatic retinopexy, scleral buckle or pars plana vitrectomy (PPV) $[4,7,8]$. Currently, surgery is the standard PVR treatment [9]. However, as the major postoperative complication of RRD, PVR is responsible for the failure of retinal reattachment surgery $[2,10,11]$. Therefore, more attention has recently been paid to the pathogenesis and treatment of PVR. To date, the pathogenesis of PVR is not yet fully understood.

Following a retinal break, the retinal pigment epithelial (RPE) cells are exposed to vitreous cavity to react to growth factors and cytokines in the vitreous, resulting in a forward feedback to secret more growth factors and cytokines to further stimulate cellular responses [4, 12]. Fibrous astrocytes, fibroblasts, myofibroblasts and macrophages were also involved in the development of PVR $[9,13]$. In eyes with PVR, RPE cells and myofibroblasts are the predominant cell type [14]. RPE is considered to be related to the formation and contraction of PVR membranes [15]. These complex processes are thought to comprise a series of events including the migration and proliferation of these ectopic cell sheets, the deposition of extracellular matrix, the formation of epiretinal membrane and subsequent contraction of the membrane (Fig. 1) $[5,12,15,16]$. In recent years, accumulating evidence has shown that inflammatory mediators, such as growth factors and cytokines, in the vitreous or in the subretinal fluid, play an important role in the occurrence and development of PVR [17-25]. In this review, we focus on the role of growth factors and cytokines in the development of PVR and the current treatment for the prevention of PVR. In addition, we support that arachidonic acid metabolic cascade is important for PVR.

We searched the PubMed database using these keywords "PVR," "inflammatory mediators," "growth factors," "cytokines" and "treatment." The search was limited to studies published up to December 2019. In this report, literatures regarding inflammatory mediators in PVR and the current treatment for PVR prevention were included. Randomized controlled trials (RCTs) of medical treatments for PVR were included. Exclusion criteria included the following: literature with low relevance to this review; no detailed and comprehensive data; use of different evaluation results. According to the title and abstract, we conducted the first screening. Based on the inclusion and exclusion criteria, the second screening was performed by reading the full text of the literatures. Finally, a total of 104 articles were included in this review. 


\section{Growth factor and cytokine hypothesis for PVR}

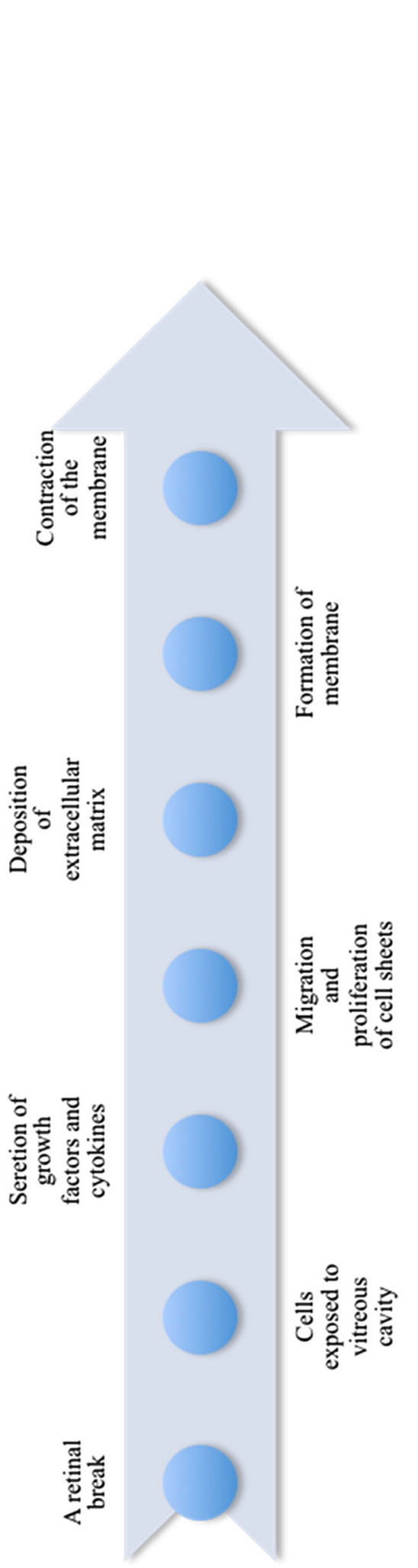

Many laboratories reported that many growth factors and cytokines were overexpressed in the vitreous or in the subretinal fluid of PVR patients [17-25]. Based on these findings, the growth factor and cytokine hypothesis was proposed. This hypothesis proposes that abnormal expression of these inflammatory mediators drives PVR, and eventually leads to formation of the epiretinal membrane and its subsequent contraction $[2,4,26]$. These growth factors and cytokines include transforming growth factor- $\beta$ (TGF- $\beta$ ), plateletderived growth factor (PDGF), basic fibroblast growth factor (bFGF), vascular endothelial growth factor (VEGF), interleukin-1alpha (IL-1 $\alpha$ ), interleukin-2 (IL-2), interleukin-3 (IL-3), interleukin-6 (IL-6), tumor necrosis factor- $\alpha$ (TNF- $\alpha)$, intercellular adhesion molecule-1 (ICAM-1) and other proteins [18-23]. Among them, TGF- $\beta$, PDGF, IL-6, IL- 8 and TNF- $\alpha$ are considered to be particularly important in this process [18-23].

Transforming growth factor- $\beta$

The TGF- $\beta$ superfamily of multifunctional mediators not only regulates cell growth and differentiation, but also promotes fibrosis and proliferation [27, 28]. Three isoforms of TGF- $\beta$, namely TGF- $\beta 1$, TGF- $\beta 2$ and TGF- $\beta 3$, are expressed in the anterior segment of the human eye [29]. In addition, TGF- $\beta 1$ was reported to be stored or activated by photoreceptors [30]. TGF- $\beta 2$ is observed in the long ciliary arteries and photoreceptor outer segments [30]. In choroid and retina, TGF- $\beta 3$ is expressed in isolated individual cells [30]. Hoerster et al. [31] reported that in rabbit models of PVR, TGF- $\beta 1$ and TGF- $\beta 2$ were dramatically upregulated in both aqueous humor $(\mathrm{AH})$ and vitreous. In addition, Kon et al. [20] observed significant elevation of TGF- $\beta 2$ in human vitreous PVR samples. RPE is considered to play an essential role in the formation and contraction of PVR membranes [15]. Of note, Yao et al. [32] pointed out that PVR progression was related to TGF- $\beta$-induced epithelial-mesenchymal transition (EMT) in RPE cells. Also, Dvashi et al. [33] showed that TGF- $\beta 1$ played a pivotal role in EMT of RPE via activation of transforming growth factor beta-activated kinase 1 (TAK1). Rojas et al. [34] highlighted that Smad7 was associated with PVR development and considered as a novel target for the 
treatment of PVR. In addition, up-regulation of Smad7, an inhibitor of TGF- $\beta$, could suppress RPE cells' fibrogenic response to EMT [35]. Consistent with these results, pirfenidone inhibited TGF- $\beta 1$ induced fibrogenesis by blocking the nuclear translocation of Smads in a human PRE cell line, ARPE-19 [36]. Later, Yang et al. [37] explored the function of long noncoding RNA (lncRNA) MALAT1 in regulating EMT in RPE cells induced by TGF- $\beta 1$. Increased expression of lncRNA MALAT1 was apparently observed in RPE cells incubated with TGF- $\beta 1$ [37]. However, knockdown of MALAT1 could result in the inhibition of TGF- $\beta 1$-induced EMT and proliferation of RPE cells partially via the activation of Smad2/3 signaling [37]. Consequently, they believed that lncRNA MALAT1 played an important role in TGF$\beta 1$-induced EMT in human RPE cells, which might shed light on the targeted therapy of PVR [37]. Researchers explored the distribution of selected cytokine gene polymorphisms in PVR patients and attempted to identify potential genetic markers [38]. Through the detection of single-nucleotide polymorphism (SNP), they found significant difference in genotype distribution of TGF- $\beta 1$ codon 10 polymorphism between PVR patients and RD patients [38]. In comparison with controls, a statistical difference in TGF- $\beta 1$ codon 25 in PVR patients was observed [38]. Therefore, they considered that TGF- $\beta 1$ genetic profile was associated with PVR development [38]. Furthermore, Carrington et al. [15] confirmed that TGF- $\beta 2$ could stimulate RPE-mediated contraction of the retina. Additionally, neutralizing antibodies against TGF- $\beta 2$ effectively inhibited RPE cell-mediated contraction [15]. Thus, TGF- $\beta 2$ may represent a potential target for PVR therapies [15]. Recently, Chen and his colleagues have investigated the function of Jagged/Notch signaling in TGF- 32 -mediated EMT in RPE cells [39]. They reported that knockdown of Jagged-1 expression and blockade of the Notch signaling pathway could suppress EMT in RPE cells induced by TGF- $\beta 2$, which might be associated with the formation of PVR [39]. During the process of TGF- $\beta 2$-mediated EMT in RPE cells, a total of 304 miRNAs were reported to have changed, of which 119 were up-regulated and 185 were down-regulated, suggesting that miRNAs might be associated with EMT in RPE cells [40]. Among them, the expression of miRNA-29b was down-regulated more than $80 \%$ [40]. Thus, Cao et al. [41] have investigated the roles of mechanical stretch and TGF- $\beta 2$ in EMT in human RPE cells and the association between miRNA-29b and PVR progression. Their observations confirmed that TGF- $\beta 2$ could not only induce EMT in RPE cells, but also suppress the expression of miRNA-29b in time-dose dependence [41]. Therefore, they speculated that miRNA-29b might have potential as part of a clinical strategy for PVR treatment [41]. Recently, Liu et al. [42] have investigated the effect of mouse double minute 2 (MDM2) on TGF- $\beta 2$-mediated EMT in RPE cells. Importantly, their experiments demonstrated that dCas9/MDM2-sgRNA could block TGF- $\beta 2$-mediated expression of MDM2 and EMT biomarkers in RPE cells [42]. In vitro, TGF- $\beta 2$ contributes to EMT, collagen production and fibrosis, while decorin antagonizes TGF- $\beta$ and exhibits independent anti-fibrosis properties [43]. Therefore, decorin, as an antifibrotic agent, might be a promising candidate for the inhibition of RPE fibrosis induced by TGF- $\beta 2$ [43]. Mony et al. [44] explored the association between TGF- $\beta 2$ mediated EMT in RPE cells and altered $\mathrm{Na}, \mathrm{K}$-ATPase expression, which was observed on the apical membrane in RPE cells. Of note, their experiments revealed that the lack of expression of $\mathrm{Na}, \mathrm{K}$-ATPase $\beta 1$ subunit might be related to TGF- $\beta 2$-mediated EMT and fibrosis in RPE cells [44]. After the activation of TGF- $\beta 2$ signaling, EMT biomarkers were found to be induced, such as fibronectin, $\alpha$-SMA pressure and actin fibers, while the decreased expression of $\beta 1$ subunit was observed [44]. Interestingly, knockdown of $\beta 1$ subunit in RPE cells could contribute to the mesenchymal cell morphology and induction of EMT biomarkers, indicating that the lack of $\mathrm{Na}, \mathrm{K}$-ATPase $\beta 1$ subunit might be a potential trigger of TGF- $\beta 2$ mediated EMT in RPE cells [44]. In addition, the reduction of $\mathrm{Na}$, K-ATPase $\beta 1$ mRNA was negatively correlated with the level of HIF-1 $\alpha$ [44]. It has been reported that the binding of HIF-1 $\alpha$ with $\mathrm{Na}$, K-ATPase $\beta 1$ promoter and the inhibition of HIF- $1 \alpha$ activity could block the decrease of $\mathrm{Na}$, K-ATPase $\beta 1$ mediated by TGF- $\beta 2$, suggesting that HIF- $1 \alpha$ might participate in the regulation of $\mathrm{Na}, \mathrm{K}$-ATPase $\beta 1$ during the EMT in RPE cells [44]. Due to the abnormal expression of TGF- $\beta$ in PVR, and the efficacy of TGF- $\beta$ inhibitors to prevent fibrogenic response, we agree that TGF- $\beta$ is likely to be associated with the development of PVR and propose TGF- $\beta$ as a candidate target for PVR therapies. However, this hypothesis still needs to be validated 
in a more precise system, such as an animal model of PVR in which TGF- $\beta$ is knocked out or knocked down.

\section{Platelet-derived growth factor (PDGF)}

Like TGF- $\beta$, many laboratories have demonstrated that PDGF and PDGF receptor (PDGFR) might participate in PVR development. Cui et al. [45] and Robbins et al. [21] confirmed that levels of both PDGF and PDGFR were significantly higher in PVR membranes than in control membranes. Both PDGF and PDGFR could be secreted by RPE and glial cells $[21,45]$. In addition, subsequent studies indicated that the level of PDGF was dramatically elevated in the vitreous of PVR patients [46]. Moreover, animal experiments supported the hypothesis that PDGF and PDGFR might participate in the complex process of PVR development [46, 47]. Most rabbit models of PVR are established by injection of fibroblasts into the vitreous [48]. In these animals, PDGF is undetectable in the vitreous of the control group, while overexpression of PDGF, especially PDGF-C, is observed in the vitreous of model rabbits [46]. Coincidentally, vitreous is reported to contain the protease necessary for PDGF-C activation [47]. Furthermore, inhibition of PDGFR expression could reduce cellular PVR formation [49, 50]. Among three isoforms of PDGFR, namely PDGFR $\alpha$, PDGFR $\beta$ and PDGFR $\alpha \beta$, PDGF-C can activate PDGFR $\alpha$ and PDGFR $\alpha \beta[46,51]$. Previous findings indicated that PDGFR $\alpha$ could be capable of triggering the events that ultimately lead to experimental PVR [52]. Recently, Zhang et al. [53] have demonstrated that crocetin could act as an effective inhibitor of PDGF-BBinduced proliferation and migration of RPE. Taken together, PDGF-C and its receptor PDGFR $\alpha$ are considered more important in the formation of PVR. Actually, besides PDGF, non-PDGF factors such as epidermal growth factor (EGF), basic fibroblast growth factor (bFGF), hepatocyte growth factor (HGF) and insulin could be capable of activating PDGFR indirectly [2, 4]. Direct activation of PDGFR $\alpha$ is driven by PDGF, causing subsequent activation of receptor's intrinsic kinase [4]. Non-PDGFs could activate $\mathrm{PDGFR} \alpha$ through reactive oxygen species (ROS) and Src family kinases (SFKs) [2, 4]. NonPDGFs could engage its receptors and increase the level of ROS, resulting in the activation of SFK and phosphorylation of PDGFR $\alpha[2,4]$. Indirect activation of PDGFR $\alpha$ pathway by Non-PDGFs could prolong the activity of signaling enzymes such as PI3K/Akt, inhibit the expression of p53 gene and thereby promote cell survival and proliferation [2, 4]. In recent years, ultrasound-targeted microbubble destruction (UTMD) and RNA interference (RNAi) have shed light on gene therapy of eye diseases and become a new research hotspot [54]. Interestingly, studies have shown that the combination of UTMD and recombinant adeno-associated virus (rAAV)-mediated RNAi targeting TGF $\beta 2$ and PDGF-B could represent a novel approach to inhibit PVR proliferation [54]. As mentioned above, both clinical studies and animal experiments support the theory that PDGF and PDGFR are implicated in the occurrence and development of PVR. These studies highlight more therapeutic targets for PVR prevention. However, a targeted therapy has not yet reached clinical trials.

\section{Interleukins}

Interleukin can be secreted by a variety of cells and stimulate cellular responses. In addition to activating and regulating immune cells, interleukin is a critical signal for abnormal proliferation, differentiation of $\mathrm{T}$ and B-lymphocytes and enhancement of inflammation $[18,55,56]$. In recent years, interleukin has been associated with the occurrence and development of PVR [18, 19, 22]. As a marker of acute inflammatory reaction, IL-6 exhibits a wide range of biologic activities. Not only can IL-6 attract chemokines, it can also recruit leukocytes to local inflammatory sites $[18,57]$. Using a multiplex bead-based immunoassay, Ricker et al. [18] investigated interleukin levels in the subretinal fluid of 21 PVR patients and 54 RRD patients. A significant increase in IL-6 was observed in the PVR cases when compared with controls [18]. Consistent with these data, Symeonidis et al. [19] reported that IL-6 was up-regulated in both vitreous and subretinal fluid in the PVR group. Most importantly, they demonstrated that IL-6 levels were positively correlated with the extent and duration of RRD and PVR grade [19]. Previous findings have shown that RPE cells, forming part of the bloodretinal barrier, were potent producers of various inflammatory cytokines including IL-6 [58]. Also, IL-6 could be secreted by other cell types. Similarly, Kon et al. [20] and EI-Ghrably et al. [59] demonstrated 
that IL-6 was a critical mediator in the complex process of postoperative PVR development. The function of IL-6 signal transduction depends on the gp130 family [60]. Recently, Lumi et al. [61] have assessed the differences in genotype distributions of single-nucleotide polymorphisms (SNPs) between PVR cases and RRD cases. Interestingly, the significant difference in genotype distribution of rs1800795 (IL-6) could be observed between PVR cases and controls [61]. Furthermore, in IL-6 (rs1800795), RRD patients with the $\mathrm{G}$ allele possibly had a higher risk of progressing into PVR than patients with the $\mathrm{C}$ gene [61]. Unfortunately, after adjustment by multiple hypothesis testing, genotype distribution of IL-6 (rs1800795) had no statistical difference between two groups [61]. Herein, in order to clarify the genetic contribution to PVR, further investigations are needed. In addition to the recruitment and activation of neutrophils, IL-8 plays a pivotal role in the regulation of inflammatory responses and mediation of angiogenesis. Interestingly, the IL-8 levels were elevated in PVR cases [62, 63]. However, IL-8 levels did not correlated with PVR grade [64]. Later, Rasier et al. [22] measured the levels of IL- 8 in 22 RRD patients and 12 cases of epiretinal membranes and macular holes. Similarly, IL-8 levels were significantly elevated in the RRD group [22]. Thus, Rasier et al. [22] speculated that IL-8 might contribute to the development of PVR. Previous report has indicated that the mRNA encoding IL-8 was obviously observed in subretinal fluid and vitreous in PVR patients [65]. Perhaps in the future, neutralizing the expression of cytokines may inhibit development of PVR. Of course, this requires further exploration.

\section{Tumor necrosis factor alpha (TNF- $\alpha)$}

TNF- $\alpha$, a member of the TNF ligand superfamily, has a wide range of biologic activities and is implicated in the regulation of inflammatory response, apoptosis and cellular proliferation [66-68]. Limb et al. [23] investigated the distribution of TNF- $\alpha$ within epiretinal membranes in 26 PVR patients. They reported that approximately $85 \%$ of the 26 epiretinal membranes contained TNF- $\alpha$ not intracellularly and in the extracellular matrix [23]. Herein, they maintained that cytokine-mediated inflammatory pathways were critical for the development of PVR [23]. In line with this result, the vitreous levels of soluble TNF-receptors
(sTNF-Rs, sTNF-RI, sTNF-RII) and TNF- $\alpha$ were found to be higher in 30 PVR cases than in 30 RRD cases [69]. Importantly, levels of sTNF-Rs were correlated with the duration of retinal detachment (RD) and grade of severity. Therefore, they hypothesized that sTNF-Rs-mediated regulation of TNF- $\alpha$ activity might effectively limit severity of retinal proliferation [69]. Previous studies have shown that adhesion and migration of RPE cells to provisional extracellular matrices(ECM) played a critical role in the formation of epiretinal membrane in PVR [70]. Jin and his colleagues investigated the effects of TNF- $\alpha$ on adhesion and migration of RPE cells to ECM and explored the mechanism of this response [70]. They pointed out that TNF- $\alpha$ could regulate RPE cells to ECM through the activation of MAPK pathway [70]. Therefore, they believed that TNF- $\alpha$ and MAPK might be the potential target for PVR therapy [70]. Recently, Wang et al. [71] have reported that it was through the activation of Akt/mTORC1 signaling that TNF- $\alpha$ could promote the migration of RPE cells by inducing the expression of matrix metallopeptidase (MMP)-9. Moreover, the expression of TNF- $\alpha$ mRNA-positive cells was obtained in epiretinal membranes in PVR patients, which might provide new direction for the treatment of PVR [72]. Although the association between various SNPs in TNF, such as rs1800629 (TNF), and the increased risk of PVR was reported, previous results could not be replicated [61]. Based on these results, we believe that TNF- $\alpha$ is implicated in the development of PVR and thus represents a therapeutic target. It will be interesting to investigate whether TNF-a-specific inhibitors, such as infliximab (remicade), could prevent or reduce PVR.

\section{Other mediators: arachidonic acid metabolite}

Besides the direct regulation of growth factors, cell functions could also be mediated through indirect mechanism, such as those regulated by arachidonic acid metabolites [73]. Observations have provided a close link between arachidonic acid metabolites and intraocular inflammation [73]. In vivo, through the cyclooxygenase (COX) pathway, lipoxygenase enzymes pathway and cytochrome P450 pathway, arachidonic acid could be metabolized to prostaglandins, thromboxane, leukotriene, epoxyeicosatrienoic acids and so on [73, 74]. In addition to regulating intraocular pressure, prostaglandins are associated 
with intraocular inflammation and the breakdown of the blood-retinal barrier [75]. Kahler et al. [73] have shown the release of arachidonic acid metabolites was found to increase rapidly and continuously after exposure of human fibroblasts to vitreous from PVR patients. Also, their experiments revealed that prostaglandin $\mathrm{E}_{2}\left(\mathrm{PGE}_{2}\right)$, which could cause continuous breakdown of aqueous blood-retinal barrier, was significantly increased in PVR cases [73]. However, as compared with controls, the release of prostaglandin $\mathrm{I}_{2}$, leukotriene $\mathrm{B}_{4}$ and thromboxane $\mathrm{A}_{2}$ was not significantly affected [73]. Also, their study demonstrated that COX inhibitors, such as acetylsalicylic acid, could effectively inhibit the release of arachidonic acid metabolites, which might provide a novel therapeutic strategy for intraocular fibrosis [73]. In addition, the exposure of RPE cells to vitreous could lead to elevated expression of membrane-associated prostaglandin E-synthase (mPGES) and cyclooxygenase (COX)-2, both of which were considered as the critical enzymes in the synthesis of prostaglandin $E_{2}$ from arachidonic acid [75]. Also, Parapuram et al. [75] pointed out that the inhibition of $\mathrm{PGE}_{2}$ production by suppressing the synthesis of mPGES could lead to the reduction in inflammation, which might provide a potential therapeutic approach to prevent the progress of PVR. More importantly, they speculated that the effect of the vitreous on the prostaglandin pathway might be related to growth factors [75]. In RPE cells, IL- $1 \beta$ was associated with the up-regulation of COX-2 and $\mathrm{PGE}_{2}$ expression [75]. The combined application of IL-1 $\beta$ and TNF- $\alpha$ or IFN-r could result in higher expression of $\mathrm{PGE}_{2}$ than treatment with IL- $1 \beta$ alone [75]. Recently, scholars have identified that the levels of prostaglandin $\mathrm{D}_{2}$ synthase $\left(\mathrm{PGD}_{2} \mathrm{~S}\right)$ were obviously increased in human PVR proteome analysis and were highly elevated in experimental PVR retina [76]. $\mathrm{PGD}_{2} \mathrm{~S}$, known as the key enzyme in the synthesis of prostaglandin $\mathrm{D}_{2}\left(\mathrm{PGD}_{2}\right)$, is connected with inflammatory response and retinal apoptosis [76]. It is known that COXs can synthesize prostaglandins from arachidonic acid [77]. On the other hand, prostaglandins can also lead to the increased synthesis of COX-2 by positive feedback mechanism [78]. Previous studies have confirmed that the expression COX-1 and COX-2 was detectable in the proliferative membranes of PVR patients [79]. At the early stages of PVR development, the administration of lornoxicam, known as nonsteroidal anti-inflammatory drugs (NSAIDs), could not only inhibit the expression of COXs in the retina and choroid, but also reduce the frequency of membrane formation by $31-43 \%$ in PVR models [77]. Recent reports have shown that calcium-independent phospholipase $A_{2}$ could regulate the proliferation of RPE cells and be identified in most transformed PRE cells in the membranes of PVR patients [80]. Thus, these observations have indicated that calcium-independent phospholipase $\mathrm{A}_{2}$ was associated with the formation of PVR membranes, which might shed light on the treatment of PVR [80]. It is well known that steroid drugs can block the effect of phospholipase $\mathrm{A}_{2}$ and inhibit the metabolism of arachidonic acid cascade [77].

\section{Treatment}

\section{Surgery}

Currently, surgery is the standard treatment for PVR [9]. The aim of PVR surgery is to reattach the retina and achieve satisfactory visual acuity. Although tremendous advances in vitreoretinal surgical techniques, such as 27-G transconjunctival sutureless vitrectomy system and noncontact wide-angle viewing system [57, 81], have been made over recent decades, both anatomic success and functional success rates are still unsatisfactory. In prospective studies, postoperative PVR occurs in $4 \%$ to $34 \%$ of cases [82]. Herein, novel therapeutic strategies are required to prevent or halt the progression of PVR.

\section{Pharmacological adjuvant therapies}

Several pharmacological adjuvant therapies have been applied to improve surgical outcomes, including antiinflammatory, anti-proliferative, antineoplastic, antigrowth factor agents and statins. (Table 1) The clinical trials (RCTs) for the evaluation of pharmacological adjuvant therapies of PVR are summarized in Table 2.

\section{Anti-inflammatory agents}

In order to inhibit inflammation in PVR, more attention has been paid to anti-inflammatory agents, especially steroids. Previously, Hui et al. [83] evaluated the efficacy of triamcinolone acetonide (TA) in the prevention of PVR in rabbit models of PVR. The incidence of RD decreased from $77.5 \%$ to 
Table 1 Pharmacological adjuvant therapies

\begin{tabular}{ll}
\hline Targets & Adjuvant agents \\
\hline Anti-inflammatory agents & Steroid (triamcinolone acetonide, crystalline cortisone, slow-release dexamethasone) \\
Anti-proliferative/antineoplastic agents & 5-Fluorouracil, daunorubicin, taxol, colchicine, retinoic acid, ribozymes \\
Anti-growth factor pathway inhibitors & Decorin, fasudil, AG1295 \\
Statins & Simvastatin \\
\hline
\end{tabular}

Pharmacological adjuvant therapies include anti-inflammatory agents, anti-proliferative/antineoplastic agents, anti-growth factor pathway inhibitors and statins. Various types of adjuvant agents are listed above

Table 2 Clinical trials (RCTs) for the evaluation of pharmacological adjuvant therapies of PVR

\begin{tabular}{|c|c|c|c|c|c|}
\hline References & Agents & Dosage & Patients & $\begin{array}{l}\text { Follow- } \\
\text { up } \\
\text { interval }\end{array}$ & Results \\
\hline $\begin{array}{l}\text { Ahmadieh } \\
\text { et al. [86] }\end{array}$ & TA & $\begin{array}{l}\text { Intravitreal injection of } 4 \mathrm{mg} \\
\mathrm{TA} \text { at the end of PPV }\end{array}$ & $\begin{array}{l}75 \text { patients } \\
\text { with } \\
\text { PVR } \\
\text { Grade C }\end{array}$ & 6 months & $\begin{array}{l}\text { No significant difference in retina } \\
\text { reattachment and postoperative visual } \\
\text { acuity between groups }\end{array}$ \\
\hline $\begin{array}{l}\text { Yamakiri } \\
\text { et al. [87] }\end{array}$ & TA & $\begin{array}{l}\text { TA-assisted PPV } \\
\text { (40 mg/5 mL solution) }\end{array}$ & $\begin{array}{l}774 \\
\text { patients }\end{array}$ & 1 year & $\begin{array}{l}\text { No significant difference in vision, } \\
\text { postoperative complications and } \\
\text { adverse events between groups }\end{array}$ \\
\hline $\begin{array}{l}\text { Banerjee } \\
\text { et al. [88] }\end{array}$ & $\begin{array}{l}\text { Slow-release } \\
\text { dexamethasone }\end{array}$ & $\begin{array}{l}\text { Injection of } 0.7 \mathrm{mg} \text { slow- } \\
\text { release dexamethasone } \\
\text { during PPV and silicone oil } \\
\text { removal }\end{array}$ & $\begin{array}{l}140 \\
\text { patients } \\
\text { with } \\
\text { PVR } \\
\text { Grade C }\end{array}$ & 2 years & $\begin{array}{l}\text { Similar results in anatomic success but } \\
\text { greater reduction in cystoid macular } \\
\text { edema at } 6 \text { months }\end{array}$ \\
\hline $\begin{array}{l}\text { Asaria et al. } \\
\text { [90] }\end{array}$ & $\begin{array}{r}5-\mathrm{FU} \text { and } \\
\text { LMWH }\end{array}$ & $\begin{array}{l}200 \mu \mathrm{g} / \mathrm{ml} 5-\mathrm{FU} \\
5 \mathrm{IU} / \mathrm{ml} \mathrm{LMWH}\end{array}$ & $\begin{array}{l}174 \\
\text { patients }\end{array}$ & 6 months & $\begin{array}{l}\text { A significant reduction in incidence of } \\
\text { postoperative PVR and reoperation } \\
\text { rate in the treatment group }\end{array}$ \\
\hline $\begin{array}{l}\text { Wickham } \\
\text { et al. [91] }\end{array}$ & $\begin{array}{r}\text { 5-FU and } \\
\text { LMWH }\end{array}$ & $\begin{array}{l}200 \mu \mathrm{g} / \mathrm{ml} \mathrm{5-FU} \\
5 \mathrm{IU} / \mathrm{ml} \mathrm{LMWH}\end{array}$ & $\begin{array}{r}641 \text { RRD } \\
\text { patients }\end{array}$ & 6 months & $\begin{array}{l}\text { No improvement in the anatomic or } \\
\text { visual success rate between groups; } \\
\text { worse visual acuity in patients with } \\
\text { macula off detachment in the } \\
\text { treatment group }\end{array}$ \\
\hline $\begin{array}{l}\text { Wiedemann } \\
\text { et al. [95] }\end{array}$ & Daunorubicin & $\begin{array}{l}10 \text { min infusion of } 7.5 \mu \mathrm{g} / \mathrm{ml} \\
\text { daunorubicin in balance } \\
\text { solution }\end{array}$ & $\begin{array}{l}286 \\
\text { patients } \\
\text { with } \\
\text { PVR } \\
\text { Grade C }\end{array}$ & 1 year & $\begin{array}{l}\text { No significant difference in anatomic } \\
\text { success rate between groups; fewer } \\
\text { reoperations in the treatment group }\end{array}$ \\
\hline $\begin{array}{l}\text { Kumar et al. } \\
\text { [96] }\end{array}$ & Daunorubicin & $\begin{array}{l}\text { Intravitreal injection of } 5 \mu \mathrm{g} \\
\text { daunorubicin }\end{array}$ & $\begin{array}{l}30 \text { patients } \\
\text { with } \\
\text { PVR } \\
\text { Grade D }\end{array}$ & 3 months & $\begin{array}{l}\text { Increased reattachment rate and better } \\
\text { visual acuity in the treatment group }\end{array}$ \\
\hline
\end{tabular}

$\overline{\text { 5-FU 5-fluorouracil; LMWH low molecular weight heparin; PVR proliferative vitreoretinopathy; RRD rhegmatogenous retinal }}$ detachment; TA triamcinolone acetonide

$13.3 \%$ following intravitreal injection of $1 \mathrm{mg}$ TA [83]. Later, Rubsamen et al. [84] demonstrated a 73\% reduction in the RD rate following periocular steroid injection in animal models of PVR. In spite of the great success achieved with steroids in animal experiments, no clinical breakthroughs have yet been made. Recently, intravitreal injection of crystalline cortisone has been found to effectively reduce 
postoperative intraocular inflammation and does not damage the intraocular structure in PVR patients [85]. In a prospective randomized controlled trial, 75 eyes with RRD and PVR grade C were randomly divided into TA treatment group and control group [86]. After 6 months, no significant difference in the retina reattachment rate and postoperative visual acuity between two groups was achieved [86]. Similarly, Yamakiri et al. [87] evaluated the oneyear results of using TA in PPV in another multicenter prospective controlled clinical trial. This study population consisted of 391 eyes that underwent TA-assisted PPV and 383 control eyes that underwent PPV [87]. Unfortunately, after one year, there was no statistical difference in vision, postoperative complications and adverse events between two groups [87]. Recently, Banerjee et al. [88] have explored the effect of adjunctive slow-release dexamethasone implant on PVR cases. A total of 140 PVR eyes that underwent PPV were randomized into standard group and treatment group [88]. An adjunctive slow-release dexamethasone implant in PVR cases, during PPV and silicone oil removal, could reduce cystoid macular edema but not improve the anatomic success rate [88].

\section{Anti-proliferative/antineoplastic agents}

PVR is described as a complex process occurring secondary to RRD and following the proliferation of ectopic cell sheets and the formation of epiretinal membrane. Thus, attempts to prevent proliferation, antineoplastic agents, like 5-fluorouracil (5-FU), daunorubicin, taxol, colchicine, retinoic acid, ribozymes and so on, have been widely studied. Among all these antineoplastic agents, 5-FU and daunorubicin are most widely used. Although 5-FU significantly prevented PVR in animal experiments, recent two randomized controlled trials were inconsistent and controversial [89-91]. Asaria et al. [90] demonstrated a significant reduction in incidence of postoperative PVR and reoperation rate in the 5-FU and low molecular weight heparin (LMWH) therapy group. However, Wickham et al. [91] noted that there was no statistical difference in anatomic or visual success rates between 5-FU and LMWH therapy group and controls. After adjuvant medication, worse final visual acuity was observed in patients with macula off detachment [91]. In addition, a Cochrane's review points out a lack of sufficient evidence of the capacity of 5-FU and LMWH to halt progression of PVR [92]. In experimental models, daunorubicin is considered to be an effective pharmacologic inhibitor of PVR progression [93, 94]. However, in recent human trails, their conclusions remained inconsistent and controversial [95, 96]. Wiedemann et al. [95] pointed out that no significant difference in anatomic success rate was obtained between groups after 6 months. Fewer reoperations were observed in daunorubicin group after one year [95]. Kumar et al. [96] indicated that the increased reattachment rate and better visual acuity were found in PVR patients treated with daunorubicin at 3-month follow-up. Thus, additional clinical trials will be necessary to evaluate the efficacy and safety of daunorubicin as an adjunctive treatment.

\section{Anti-growth factor pathway inhibitors}

Based on the growth factor and cytokine hypothesis, inhibitors with anti-growth factor pathway activity have been considered promising candidates for PVR treatment. Decorin, a naturally occurring TGF- $\beta$ inhibitor, has shown positive results in terms of reducing fibrosis and tractional retinal detachment (TRD) development in rabbit models of PVR [97]. Thus, adjuvant decorin application during PPV may represent an effective therapeutic approach in prevention of PVR reactions without apparent histopathological toxicity to the eyes [97]. A key downstream mediator of TGF- $\beta$, Rho-kinase (ROCK) (which is implicated in cell adhesion, migration, proliferation and apoptosis [98]) is also a target for PVR therapy. Indeed, fasudil, a potent and selective ROCK inhibitor, has already proved to be effective in halting PVR progression in rabbit models [98]. Herein, ROCK inhibition provides a novel therapeutic strategy for the management of PVR and more clinical trials with fasudil need to be performed. AG1295, a specific inhibitor of PDGFR, has shown promising results in animal experiments [50]. In a recent study, Zheng et al. [50] used rabbit models of PVR to investigate the effect of AG1295 on PVR development. Amazingly, development of TRD was markedly attenuated in the AG1295-treated group [50]. Therefore, AG1295 appeared to be an efficacious therapeutic target for preventing PVR progression [50]. 


\section{Statins}

Statins are widely prescribed to reduce the risk of cardiovascular events [99]. Administration of statins may also ameliorate osteoporosis and the growth and metastasis of cancer [100, 101]. Recently, the application of statins in vitreoretinal diseases, such as PDR and RVR, has become a research hot spot [102-104]. In the last decade, statins have been reported to effectively prevent proliferation of PVR and reduce the need for further surgical interventions in postoperative RRD patients [103, 104]. Therefore, statins may represent a new strategy to prevent PVR development. Importantly, Kawahara et al. [102] demonstrated that vitreous samples from PVR and PDR patients enhanced the phosphorylation of myosin light chain and gel contraction, while simvastatin could almost completely inhibit these phenomena in a dosedependent manner without apparent toxicity. In addition, simvastatin could suppress the development of PVR in animal models [102]. The PVR models were established by injection of fibroblasts into each rabbit's right eye. Six rabbits in the first group received intravitreal injection of $0.1 \mathrm{~mL}$ equilibrium salt solution, and seven rabbits in the second and third groups received intravitreal injection of $0.1 \mathrm{~mL}$ vehicle containing $5 \mu \mathrm{mol} / 1$ and $15 \mu \mathrm{mol} / \mathrm{l}$ of simvastatin, respectively [102]. As a result, the first group developed PVR, forming proliferative membranes, while simvastatin inhibited development of PVR [102]. In a retrospective study, researchers compared the levels of inflammatory mediators, including angiopoietin (ANGPT)-1 and -2, TGF- $\beta 1$, VEGF and matrix metalloproteinase (MMP)-2 and (MMP)-9, between the vitreous of 14 RRD patients treated with statins and 82 RRD patients without statin treatment [103]. Amazingly, they found that the levels of ANGPT-2, VEGF and MMP-2 were significantly lower in the eyes of RRD patients taking statins [103]. Moreover, they noted that RRD patients taking statins tended to have better one-month best-corrected visual acuity (BCVA) [103]. The implications of these findings are limited by the study's sample size. Therefore, large RTCs are urgently needed to evaluate the efficacy and safety of statins in the treatment of PVR. Later, Loukovaara et al. [104] analyzed the relationship between statins and further surgical intervention after primary vitrectomy in 5709 patients with vitreoretinal disease. Among them, there were 1916 RRD patients, accounting for nearly $1 / 3$ of the total patients [104]. In this study, preoperative use of statins was associated with a $28 \%$ reduction in the rate of further surgical intervention in RRD patients [104]. Thus, they suggest that statins may represent an efficacious treatment for PVR [104]. However, questions remain about use of statins. The role of statin therapy in PVR is not yet fully understood. Which age groups should take statins, for how long and at what dose? Whether preoperative oral statins or intraoperative intravitreal injection of statins can obtain higher surgical success rates and lower the rate of further surgical intervention remains to be seen. Thus, more animal experiments and RTCs are necessary to explore the use of statins as adjuvant drugs in the treatment of PVR.

\section{Conclusion}

Despite great advances in surgical techniques, PVR remains a common cause of severe vision loss. This sight-threatening disorder comprises a series of events including cell migration, cell proliferation and formation of epiretinal membrane [5, 12, 15]. With improved understanding of the pathogenesis of PVR, many laboratories have proposed growth factor and cytokine hypothesis and presented sufficient evidences. These growth factors and cytokines act as signaling molecules to trigger more mediator secretion, amplify the inflammatory reaction and eventually lead to the formation of proliferative membranes. More importantly, the identification of inflammatory mediators provides novel and efficacious therapeutic targets for the treatment of PVR. Various pharmacological adjuvant agents have been extensively investigated. Some agents have been found to ameliorate PVR progression in animal models, but the limited clinical studies were not conclusive-perhaps due to small sample size or short-term follow-up time. Certainly, more work needs to be done to halt the progression of PVR, improve the rate of retinal reattachment and achieve satisfactory vision. 
Acknowledgements We thank Hong Wang for reviewing the manuscript and providing constructive input.

\section{Compliance with ethical standards}

Conflict of interest All authors declare that they have no conflict of interest.

Ethical approval This article does not contain any studies with human participants performed by any of the authors.

Open Access This article is licensed under a Creative Commons Attribution 4.0 International License, which permits use, sharing, adaptation, distribution and reproduction in any medium or format, as long as you give appropriate credit to the original author(s) and the source, provide a link to the Creative Commons licence, and indicate if changes were made. The images or other third party material in this article are included in the article's Creative Commons licence, unless indicated otherwise in a credit line to the material. If material is not included in the article's Creative Commons licence and your intended use is not permitted by statutory regulation or exceeds the permitted use, you will need to obtain permission directly from the copyright holder. To view a copy of this licence, visit http://creativecommons.org/licenses/by/4.0/.

\section{References}

1. Hilton $\mathrm{G}$ et al (1983) The classification of retinal detachment with proliferative vitreoretinopathy. Ophthalmology 90(2):121-125

2. Moysidis SN, Thanos A, Vavvas DG (2012) Mechanisms of inflammation in proliferative vitreoretinopathy: from bench to bedside. Mediat Inflamm 2012:815937

3. Ciprian D (2015) The pathogeny of proliferative vitreoretinopathy. Rom J Ophthalmol 59(2):88-92

4. Pennock S, Haddock LJ, Eliott D, Mukai S, Kazlauskas A (2014) Is neutralizing vitreal growth factors a viable strategy to prevent proliferative vitreoretinopathy? Prog Retin Eye Res 40:16-34

5. Pastor JC, Rojas J, Pastor-Idoate S, Di Lauro S, GonzalezBuendia L, Delgado-Tirado S (2016) Proliferative vitreoretinopathy: a new concept of disease pathogenesis and practical consequences. Prog Retin Eye Res 51:125-155

6. Girard P, Mimoun G, Karpouzas I, Montefiore G (1994) Clinical risk factors for proliferative vitreoretinopathy after retinal detachment surgery. Retina 14(5):417-424

7. Cardillo JA, Stout JT, LaBree L, Azen SP, Omphroy L, Cui JZ, Kimura H, Hinton DR, Ryan SJ (1997) Post-traumatic proliferative vitreoretinopathy. The epidemiologic profile, onset, risk factors, and visual outcome. Ophthalmology 104(7):1166-1173

8. Feng K, Hu Y, Wang C, Shen L, Pang X, Jiang Y, Nie H, Wang Z, Ma Z (2013) Risk factors, anatomical, and visual outcomes of injured eyes with proliferative vitreoretinopathy: eye injury vitrectomy study. Retina 33(8):1512-1518
9. Sadaka A, Giuliari GP (2012) Proliferative vitreoretinopathy: current and emerging treatments. Clin Ophthalmol (Auckl, NZ) 6:1325-1333

10. Ryan SJ (1985) The pathophysiology of proliferative vitreoretinopathy in its management. Am J Ophthalmol 100(1):188-193

11. Kwon OW, Song JH, Roh MI (2016) Retinal detachment and proliferative vitreoretinopathy. Dev Ophthalmol 55:154-162

12. Campochiaro PA, Sugg R, Grotendorst G, Hjelmeland LM (1989) Retinal pigment epithelial cells produce PDGF-like proteins and secrete them into their media. Exp Eye Res 49(2):217-227

13. Tikhonovich MV, Iojleva EJ, Gavrilova SA (2015) The role of inflammation in the development of proliferative vitreoretinopathy. Klin Med (Mosk) 93(7):14-20

14. Guenther SR, Schumann RG, Hagenau F, Wolf A, Priglinger SG, Vogt D (2019) Comparison of surgically excised premacular membranes in eyes with macular pucker and proliferative vitreoretinopathy. Curr Eye Res 44(3):341-349

15. Carrington L, McLeod D, Boulton M (2000) IL-10 and antibodies to TGF- $\beta 2$ and PDGF inhibit RPE-mediated retinal contraction. Invest Ophthalmol Vis Sci 41(5):1210-1216

16. Rouberol F, Chiquet C (2014) Proliferative vitreoretinopathy: pathophysiology and clinical diagnosis. J Fr Ophtalmol 37(7):557-565

17. Ricker LJ, Altara R, Goezinne F, Hendrikse F, Kijlstra A, La Heij EC (2011) Soluble apoptotic factors and adhesion molecules in rhegmatogenous retinal detachment. Invest Ophthalmol Vis Sci 52(7):4256-4262

18. Ricker LJ, Kijlstra A, Kessels AG, de Jager W, Liem AT, Hendrikse F, La Heij EC (2011) Interleukin and growth factor levels in subretinal fluid in rhegmatogenous retinal detachment: a case-control study. PLoS ONE 6(4):e19141

19. Symeonidis C, Papakonstantinou E, Androudi S, Georgalas I, Rotsos T, Karakiulakis G, Diza E, Dimitrakos SA (2014) Comparison of interleukin-6 and matrix metalloproteinase expression in the subretinal fluid and the vitreous during proliferative vitreoretinopathy: correlations with extent, duration of RRD and PVR grade. Cytokine 67(2):71-76

20. Kon CH, Occleston NL, Aylward GW, Khaw PT (1999) Expression of vitreous cytokines in proliferative vitreoretinopathy: a prospective study. Invest Ophthalmol Vis Sci 40(3):705-712

21. Robbins SG, Mixon RN, Wilson DJ, Hart CE, Robertson JE, Westra I, Planck SR, Rosenbaum JT (1994) Plateletderived growth factor ligands and receptors immunolocalized in proliferative retinal diseases. Invest Ophthalmol Vis Sci 35(10):3649-3663

22. Rasier R, Gormus U, Artunay O, Yuzbasioglu E, Oncel M, Bahcecioglu H (2010) Vitreous levels of VEGF, IL-8, and TNF- $\alpha$ in retinal detachment. Curr Eye Res 35(6):505-509

23. Limb GA, Alam A, Earley O, Green W, Chignell AH, Dumonde DC (1994) Distribution of cytokine proteins within epiretinal membranes in proliferative vitreoretinopathy. Curr Eye Res 13(11):791-798 
24. Kumar A, Li X (2018) PDGF-C and PDGF-D in ocular diseases. Mol Aspects Med 62:33-43

25. Bastiaans J, van Meurs JC, Mulder VC, Nagtzaam NM, Smits-te Nijenhuis M, Dufour-van den Goorbergh DC, van Hagen PM, Hooijkaas H, Dik WA (2014) The role of thrombin in proliferative vitreoretinopathy. Invest Ophthalmol Vis Sci 55(7):4659-4666

26. Morescalchi F, Duse S, Gambicorti E, Romano MR, Costagliola C, Semeraro F (2013) Proliferative vitreoretinopathy after eye injuries: an overexpression of growth factors and cytokines leading to a retinal keloid. Mediat Inflamm 2013:269787

27. Martins T, Eusebio N, Correia A, Marinho J, Casares F, Pereira PS (2017) TGF $\beta /$ Activin signalling is required for ribosome biogenesis and cell growth in Drosophila salivary glands. Open Biol 7(1):160258

28. Sefat F, Youseffi M, Khaghani SA, Soon CF, Javid F (2016) Effect of transforming growth factor- $\beta 3$ on mono and multilayer chondrocytes. Cytokine 83:118-126

29. Pasquale LR, Dorman-Pease ME, Lutty GA, Quigley HA, Jampel HD (1993) Immunolocalization of TGF-beta 1, TGF-beta 2, and TGF-beta 3 in the anterior segment of the human eye. Invest Ophthalmol Vis Sci 34(1):23-30

30. Lutty GA, Merges C, Threlkeld AB, Crone S, McLeod DS (1993) Heterogeneity in localization of isoforms of TGF- $\beta$ in human retina, vitreous, and choroid. Invest Ophthalmol Vis Sci 34(3):477-487

31. Hoerster R, Muether PS, Vierkotten S, Hermann MM, Kirchhof B, Fauser S (2014) Upregulation of TGF- $\beta 1$ in experimental proliferative vitreoretinopathy is accompanied by epithelial to mesenchymal transition. Graefes Arch Clin Exp Ophthalmol 252(1):11-16

32. Yao H, Ge T, Zhang Y, Li M, Yang S, Li H, Wang F (2019) BMP7 antagonizes proliferative vitreoretinopathy through retinal pigment epithelial fibrosis in vivo and in vitro. FASEB J 33(3):3212-3224

33. Dvashi Z, Goldberg M, Adir O, Shapira M, Pollack A (2015) TGF- $\beta 1$ induced transdifferentiation of rpe cells is mediated by TAK1. PLoS ONE 10(4):e0122229

34. Rojas J, Fernandez I, Pastor JC, Maclaren RE, Ramkissoon Y, Harsum S, Charteris DG, Van Meurs JC, Amarakoon S, Ruiz-Moreno JM, Rocha-Sousa A, Brion M, Carracedo A (2013) A genetic case-control study confirms the implication of SMAD7 and TNF locus in the development of proliferative vitreoretinopathy. Invest Ophthalmol Vis Sci 54(3):1665-1678

35. Saika S, Yamanaka O, Nishikawa-Ishida I, Kitano A, Flanders KC, Okada Y, Ohnishi Y, Nakajima Y, Ikeda K (2007) Effect of Smad7 gene overexpression on transforming growth factor $\beta$-induced retinal pigment fibrosis in a proliferative vitreoretinopathy mouse model. Arch Ophthalmol 125(5):647-654

36. Choi K, Lee K, Ryu SW, Im M, Kook KH, Choi C (2012) Pirfenidone inhibits transforming growth factor- $\beta 1$-induced fibrogenesis by blocking nuclear translocation of Smads in human retinal pigment epithelial cell line ARPE19. Molecular vision 18:1010-1020

37. Yang S, Yao H, Li M, Li H, Wang F (2016) Long noncoding RNA MALAT1 mediates transforming growth factor $\beta 1$-induced epithelial-mesenchymal transition of retinal pigment epithelial cells. PLoS ONE 11(3):e0152687

38. Sanabria Ruiz-Colmenares MR, Pastor Jimeno JC, Garrote Adrados JA, Telleria Orriols JJ, Yugueros Fernandez MI (2006) Cytokine gene polymorphisms in retinal detachment patients with and without proliferative vitreoretinopathy: a preliminary study. Acta Ophthalmol Scand 84(3):309-313

39. Chen X, Xiao W, Liu X, Zeng M, Luo L, Wu M, Ye S, Liu Y (2014) Blockade of Jagged/Notch pathway abrogates transforming growth factor $\beta 2$-induced epithelial-mesenchymal transition in human retinal pigment epithelium cells. Curr Mol Med 14(4):523-534

40. Chen X, Ye S, Xiao W, Luo L, Liu Y (2014) Differentially expressed microRNAs in TGF $\beta 2$-induced epithelial-mesenchymal transition in retinal pigment epithelium cells. Int J Mol Med 33(5):1195-1200

41. Cao Q, Deji QZ, Liu YJ, Ye W, Zhaba WD, Jiang Q, Yan F (2019) The role of mechanical stretch and TGF- $\beta 2$ in epithelial-mesenchymal transition of retinal pigment epithelial cells. Int J Ophthalmol 12(12):1832-1838

42. Liu B, Song J, Han H, Hu Z, Chen N, Cui J, Matsubara JA, Zhong J, Lei H (2019) Blockade of MDM2 with inactive Cas9 prevents epithelial to mesenchymal transition in retinal pigment epithelial cells. Lab Invest 99(12):1874-1886

43. Begum G, O’Neill J, Chaudhary R, Blachford K, Snead DRJ, Berry M, Scott RAH, Logan A, Blanch RJ (2018) Altered decorin biology in proliferative vitreoretinopathy: a mechanistic and cohort study. Invest Ophthalmol Vis Sci 59(12):4929-4936

44. Mony S, Lee SJ, Harper JF, Barwe SP, Langhans SA (2013) Regulation of Na, K-ATPase $\beta 1$-subunit in TGF$\beta 2$-mediated epithelial-to-mesenchymal transition in human retinal pigmented epithelial cells. Exp Eye Res 115:113-122

45. Cui JZ, Chiu A, Maberley D, Ma P, Samad A, Matsubara JA (2007) Stage specificity of novel growth factor expression during development of proliferative vitreoretinopathy. Eye (Lond) 21(2):200-208

46. Lei H, Hovland P, Velez G, Haran A, Gilbertson D, Hirose T, Kazlauskas A (2007) A potential role for PDGF-C in experimental and clinical proliferative vitreoretinopathy. Invest Ophthalmol Vis Sci 48(5):2335-2342

47. Lei H, Velez G, Hovland P, Hirose T, Kazlauskas A (2008) Plasmin is the major protease responsible for processing PDGF-C in the vitreous of patients with proliferative vitreoretinopathy. Invest Ophthalmol Vis Sci 49(1):42-48

48. Agrawal RN, He S, Spee C, Cui JZ, Ryan SJ, Hinton DR (2007) In vivo models of proliferative vitreoretinopathy. Nat Protoc 2(1):67-77

49. Ikuno Y, Leong FL, Kazlauskas A (2000) Attenuation of experimental proliferative vitreoretinopathy by inhibiting the platelet-derived growth factor receptor. Invest Ophthalmol Vis Sci 41(10):3107-3116

50. Zheng Y, Ikuno Y, Ohj M, Kusaka S, Jiang R, Cekic O, Sawa M, Tano Y (2003) Platelet-derived growth factor receptor kinase inhibitor AG1295 and inhibition of experimental proliferative vitreoretinopathy. Jpn J Ophthalmol 47(2):158-165 
51. Li X, Ponten A, Aase K, Karlsson L, Abramsson A, Uutela M, Backstrom G, Hellstrom M, Bostrom H, Li H, Soriano P, Betsholtz C, Heldin CH, Alitalo K, Ostman A, Eriksson $\mathrm{U}$ (2000) PDGF-C is a new protease-activated ligand for the PDGF $\alpha$-receptor. Nat Cell Biol 2(5):302-309

52. Andrews A, Balciunaite E, Leong FL, Tallquist M, Soriano P, Refojo M, Kazlauskas A (1999) Platelet-derived growth factor plays a key role in proliferative vitreoretinopathy. Invest Ophthalmol Vis Sci 40(11):2683-2689

53. Zhang H, Shang Q, An J, Wang C, Ma J (2019) Crocetin inhibits PDGF-BB-induced proliferation and migration of retinal pigment epithelial cells. Eur $\mathrm{J}$ Pharmacol 842:329-337

54. Zheng X, Du L, Wang H, Gu Q (2012) A novel approach to attenuate proliferative vitreoretinopathy using ultrasoundtargeted microbubble destruction and recombinant adenoassociated virus-mediated RNA interference targeting transforming growth factor- $\beta 2$ and platelet-derived growth factor-B. J Gene Med 14(5):339-347

55. Alderson MR, Pike BL, Harada N, Tominaga A, Takatsu K, Nossal GJ (1987) Recombinant T cell replacing factor (interleukin 5) acts with antigen to promote the growth and differentiation of single hapten-specific B lymphocytes. J Immunol 139(8):2656-2660

56. Takatsu K, Kikuchi Y, Takahashi T, Honjo T, Matsumoto M, Harada N, Yamaguchi N, Tominaga A (1987) Interleukin 5, a T-cell-derived B-cell differentiation factor also induces cytotoxic T lymphocytes. Proc Natl Acad Sci USA 84(12):4234-4238

57. Dai Y, Wu Z, Sheng H, Zhang Z, Yu M, Zhang Q (2015) Identification of inflammatory mediators in patients with rhegmatogenous retinal detachment associated with choroidal detachment. Mol Vis 21:417-427

58. Holtkamp GM, Van Rossem M, de Vos AF, Willekens B, Peek R, Kijlstra A (1998) Polarized secretion of IL-6 and IL-8 by human retinal pigment epithelial cells. Clin Exp Immunol 112(1):34-43

59. El-Ghrably IA, Dua HS, Orr GM, Fischer D, Tighe PJ (2001) Intravitreal invading cells contribute to vitreal cytokine milieu in proliferative vitreoretinopathy. $\mathrm{Br} \mathrm{J}$ Ophthalmol 85(4):461-470

60. Wang X, Miller EB, Goswami M, Zhang P, Ronning KE, Karlen SJ, Zawadzki RJ, Pugh EN Jr, Burns ME (2017) Rapid monocyte infiltration following retinal detachment is dependent on non-canonical IL6 signaling through gp130. J Neuroinflammation 14(1):121

61. Lumi X, Jelen MM, Zupan A, Bostjancic E, Ravnik-Glavac M, Hawlina M, Glavac D (2019) Single nucleotide polymorphisms in retinal detachment patients with and without proliferative vitreoretinopathy. Retina 22(10):0000000000002477

62. Banerjee S, Savant V, Scott RA, Curnow SJ, Wallace GR, Murray PI (2007) Multiplex bead analysis of vitreous humor of patients with vitreoretinal disorders. Invest Ophthalmol Vis Sci 48(5):2203-2207

63. Canataroglu H, Varinli I, Ozcan AA, Canataroglu A, Doran F, Varinli S (2005) Interleukin (IL)-6, interleukin (IL)-8 levels and cellular composition of the vitreous humor in proliferative diabetic retinopathy, proliferative vitreoretinopathy, and traumatic proliferative vitreoretinopathy. Ocul Immunol Inflamm 13(5):375-381
64. Aksunger A, Or M, Okur H, Hasanreisoglu B, Akbatur H (1997) Role of interleukin 8 in the pathogenesis of proliferative vitreoretinopathy. Ophthalmologica 211(4):223-225

65. El-Ghrably IA, Dua HS, Orr GM, Fischer D, Tighe PJ (1999) Detection of cytokine mRNA production in infiltrating cells in proliferative vitreoretinopathy using reverse transcription polymerase chain reaction. $\mathrm{Br} \mathrm{J}$ Ophthalmol 83(11):1296-1299

66. Zhao X, Lv C, Chen S, Zhi F (2018) A role for the nonreceptor tyrosine kinase ACK1 in TNF- $\alpha$-mediated apoptosis and proliferation in human intestinal epithelial caco-2 cells. Cell Biol Int 42(9):1097-1105

67. Zhang B, Wu T, Wang Z, Zhang Y, Wang J, Yang B, Zhao Y, Rao Z, Gao J (2015) p38MAPK activation mediates tumor necrosis factor- $\alpha$-induced apoptosis in glioma cells. Mol Med Rep 11(4):3101-3107

68. Qi L, Zhi J, Zhang T, Cao X, Sun L, Xu Y, Li X (2015) Inhibition of microRNA-25 by tumor necrosis factor alpha is critical in the modulation of vascular smooth muscle cell proliferation. Mol Med Rep 11(6):4353-4358

69. Limb GA, Hollifield RD, Webster L, Charteris DG, Chignell AH (2001) Soluble TNF receptors in vitreoretinal proliferative disease. Invest Ophthalmol Vis Sci 42(7):1586-1591

70. Jin M, He S, Worpel V, Ryan SJ, Hinton DR (2000) Promotion of adhesion and migration of RPE cells to provisional extracellular matrices by TNF- $\alpha$. Invest Ophthalmol Vis Sci 41(13):4324-4332

71. Wang CH, Cao GF, Jiang Q, Yao J (2012) TNF- $\alpha$ promotes human retinal pigment epithelial (RPE) cell migration by inducing matrix metallopeptidase 9 (MMP-9) expression through activation of $\mathrm{Akt} / \mathrm{mTORC} 1$ signaling. Biochem Biophys Res Commun 425(1):33-38

72. Limb GA, Earley O, Jones SE, LeRoy F, Chignell AH, Dumonde DC (1994) Expression of mRNA coding for TNF $\alpha$, IL-1 $\beta$ and IL- 6 by cells infiltrating retinal membranes. Graefes Arch Clin Exp Ophthalmol 232(11):646-651

73. Kahler CM, Herold M, Kaufmann G, Pischel AB, Schratzberger P, Reinisch N, Gruber B, Bellmann R, Dunzendorfer S, Kieselbach G, Wiedermann CJ (1998) Induction of arachidonic acid metabolite release by human fibroblasts in proliferative vitreoretinopathy. Eur J Pharmacol 341(1):111-117

74. Amara IE, Elshenawy OH, Abdelrady M, El-Kadi AO (2014) Acute mercury toxicity modulates cytochrome $\mathrm{P} 450$, soluble epoxide hydrolase and their associated arachidonic acid metabolites in $\mathrm{C} 57 \mathrm{Bl} / 6$ mouse heart. Toxicol Lett 226(1):53-62

75. Parapuram SK, Ganti R, Hunt RC, Hunt DM (2003) Vitreous induces components of the prostaglandin E2 pathway in human retinal pigment epithelial cells. Invest Ophthalmol Vis Sci 44(4):1767-1774

76. Kuo HK, Chen YH, Huang F, Wu YC, Shiea J, Wu PC (2016) The upregulation of zinc finger protein 670 and prostaglandin D2 synthase in proliferative vitreoretinopathy. Graefes Arch Clin Exp Ophthalmol 254(2):205-213

77. Tikhonovich MV, Erdiakov AK, Gavrilova SA (2018) Nonsteroid anti-inflammatory therapy suppresses the development of proliferative vitreoretinopathy more 
effectively than a steroid one. Int Ophthalmol 38(4):1365-1378

78. Vichai V, Suyarnsesthakorn C, Pittayakhajonwut D, Sriklung K, Kirtikara K (2005) Positive feedback regulation of COX-2 expression by prostaglandin metabolites. Inflamm Res 54(4):163-172

79. Tikhonovich M, Lyskin P, Ioyleva E, Gavrilova S (2016) Expression of cyclooxygenases and trophic and growth factors in epiretinal membranes at late stages of proliferative vitreoretinopathy. Graefes Arch Clin Exp Ophthalmol 254(11):2277-2279

80. Kolko M, Kiilgaard JF, Wang J, Poulsen KA, Andreasen JR, la Cour M, Nissen MH, Heegaard S, Bazan NG, Prause JU (2009) Calcium-independent phospholipase A2 regulates retinal pigment epithelium proliferation and may be important in the pathogenesis of retinal diseases. Exp Eye Res 89(3):383-391

81. Oshima Y, Wakabayashi T, Sato T, Ohji M, Tano Y (2010) A 27-gauge instrument system for transconjunctival sutureless microincision vitrectomy surgery. Ophthalmology 117(1):93-102.e2

82. Leiderman YI, Miller JW (2009) Proliferative vitreoretinopathy: pathobiology and therapeutic targets. Semin Ophthalmol 24(2):62-69

83. Hui YN, Liang HC, Cai YS, Kirchhof B, Heimann K (1993) Corticosteroids and daunomycin in the prevention of experimental proliferative vitreoretinopathy induced by macrophages. Graefes Arch Clin Exp Ophthalmol 231(2):109-114

84. Rubsamen PE, Cousins SW (1997) Therapeutic effect of periocular corticosteroids in experimental proliferative vitreoretinopathy. Retina (Phila, Pa) 17(1):44-50

85. Jonas JB, Hayler JK, Panda-Jonas S (2000) Intravitreal injection of crystalline cortisone as adjunctive treatment of proliferative vitreoretinopathy. $\mathrm{Br} \mathrm{J}$ Ophthalmol 84(9): 1064-1067

86. Ahmadieh H, Feghhi M, Tabatabaei H, Shoeibi N, Ramezani A, Mohebbi MR (2008) Triamcinolone acetonide in silicone-filled eyes as adjunctive treatment for proliferative vitreoretinopathy: a randomized clinical trial. Ophthalmology 115(11):1938-1943

87. Yamakiri K, Sakamoto T, Noda Y, Nakahara M, Ogino N, Kubota T, Yokoyama M, Furukawa M, Ishibashi T (2008) One-year results of a multicenter controlled clinical trial of triamcinolone in pars plana vitrectomy. Graefes Arch Clin Exp Ophthalmol 246(7):959-966

88. Banerjee PJ, Quartilho A, Bunce C, Xing W, Zvobgo TM, Harris N, Charteris DG (2017) Slow-release dexamethasone in proliferative vitreoretinopathy: a prospective. Randomized Control Clin Trial Ophthalmol 124(6):757-767

89. Borhani H, Peyman GA, Rahimy MH, Thompson H (1995) Suppression of experimental proliferative vitreoretinopathy by sustained intraocular delivery of 5-FU. Int Ophthalmol 19(1):43-49

90. Asaria RH, Kon CH, Bunce C, Charteris DG, Wong D, Khaw PT, Aylward GW (2001) Adjuvant 5-fluorouracil and heparin prevents proliferative vitreoretinopathy: results from a randomized, double-blind, controlled clinical trial. Ophthalmology 108(7):1179-1183
91. Wickham L, Bunce C, Wong D, McGurn D, Charteris DG (2007) Randomized controlled trial of combined 5-Fluorouracil and low-molecular-weight heparin in the management of unselected rhegmatogenous retinal detachments undergoing primary vitrectomy. Ophthalmology 114(4):698-704

92. Sundaram V, Barsam A, Virgili G (2013) Intravitreal low molecular weight heparin and 5-Fluorouracil for the prevention of proliferative vitreoretinopathy following retinal reattachment surgery. Cochrane Database Syst Rev 1:CD006421

93. Khawly JA, Saloupis P, Hatchell DL, Machemer R (1991) Daunorubicin treatment in a refined experimental model of proliferative vitreoretinopathy. Graefe's Arch Clin Exp Ophthalmol 229(5):464-467

94. Chen EP, Steinhorst UH, Samsa GP, Saloupis PT, Hatchell DL (1992) The effect of combined daunorubicin and triamcinolone acetonide treatment on a refined experimental model of proliferative vitreoretinopathy. Invest Ophthalmol Vis Sci 33(7):2160-2164

95. Wiedemann P, Hilgers RD, Bauer P, Heimann K, Daunomycin Study Group (1998) Adjunctive daunorubicin in the treatment of proliferative vitreoretinopathy: results of a multicenter clinical trial. Am J Ophthalmol 126(4):550-559

96. Kumar A, Nainiwal S, Choudhary I, Tewari HK, Verma LK (2002) Role of daunorubicin in inhibiting proliferative vitreoretinopathy after retinal detachment surgery. Clin Exp Ophthalmol 30(5):348-351

97. Nassar K, Luke J, Luke M, Kamal M, Abd El-Nabi E, Soliman M, Rohrbach M, Grisanti S (2011) The novel use of decorin in prevention of the development of proliferative vitreoretinopathy (PVR). Graefes Arch Clin Exp Ophthalmol 249(11):1649-1660

98. Kita T, Hata Y, Arita R, Kawahara S, Miura M, Nakao S, Mochizuki Y, Enaida H, Goto Y, Shimokawa H, HafeziMoghadam A, Ishibashi T (2008) Role of TGF- $\beta$ in proliferative vitreoretinal diseases and ROCK as a therapeutic target. Proc Natl Acad Sci USA 105(45):17504-17509

99. Heart Protection Study Collaborative Group (2002) MRC/ BHF heart protection study of cholesterol lowering with simvastatin in 20,536 high-risk individuals: a randomised placebo-controlled trial. Lancet 360(9326):7-22

100. Coons JC (2002) Hydroxymethylglutaryl-coenzyme A reductase inhibitors in osteoporosis management. Ann Pharmacother 36(2):326-330

101. Campbell MJ, Esserman LJ, Zhou Y, Shoemaker M, Lobo M, Borman E, Baehner F, Kumar AS, Adduci K, Marx C, Petricoin EF, Liotta LA, Winters M, Benz S, Benz CC (2006) Breast cancer growth prevention by statins. Cancer Res 66(17):8707-8714

102. Kawahara S, Hata Y, Kita T, Arita R, Miura M, Nakao S, Mochizuki Y, Enaida H, Kagimoto T, Goto Y, HafeziMoghadam A, Ishibashi T (2008) Potent inhibition of cicatricial contraction in proliferative vitreoretinal diseases by statins. Diabetes 57(10):2784-2793

103. Tuuminen R, Haukka J, Loukovaara S (2015) Statins in rhegmatogenous retinal detachment are associated with low intravitreal angiopoietin-2, VEGF and MMP-2 levels, and improved visual acuity gain in vitrectomized patients. Graefes Arch Clin Exp Ophthalmol 253(10):1685-1693 
104. Loukovaara S, Sahanne S, Takala A, Haukka J (2018) Statin use and vitreoretinal surgery: findings from a Finnish population-based cohort study. Acta Ophthalmol 96(5):442-451
Publisher's Note Springer Nature remains neutral with regard to jurisdictional claims in published maps and institutional affiliations. 